\title{
The Social Determinants of Health and the Role of the Health Care System: A Case Study of the Significance of Good Governance in Public Hospitals in South Africa
}

\author{
Adam Fusheini' ${ }^{1,2}$, John Eyles ${ }^{1,3}$, Jane Goudge ${ }^{1}$ \\ ${ }^{1}$ Centre for Health Policy/MRC Health Policy Research Group, School of Public Health, Faculty of Health Sciences, University of the \\ Witwatersrand, Johannesburg, South Africa \\ ${ }^{2}$ Department of Health Policy, Planning and Management' School of Public Health, University of Health and Allied Sciences, Ho, Ghana \\ ${ }^{3}$ School of Geography and Earth Sciences, McMaster University, Hamilton, Canada \\ Email: adam.fusheini@gmail.com
}

How to cite this paper: Fusheini, A., Eyles, J. and Goudge, J. (2016) The Social Determinants of Health and the Role of the Health Care System: A Case Study of the Significance of Good Governance in Public Hospitals in South Africa. Health, 8, 12881306.

http://dx.doi.org/10.4236/health.2016.812131

Received: August 16, 2016

Accepted: September 25, 2016

Published: September 28, 2016

Copyright $\odot 2016$ by authors and Scientific Research Publishing Inc. This work is licensed under the Creative Commons Attribution International License (CC BY 4.0).

http://creativecommons.org/licenses/by/4.0/

\begin{abstract}
Increasingly international and national policies are being directed at actions for the social determinants of health and for an integrated approach to health care provision, not only in terms of institutional co-operation but also stakeholder involvement. A key component of both these policies is the development of good governance principles in all health care agencies and organizations. A neglected dimension in these debates has been the role of the public hospital which remains a vital and expensive dimension of service provision. In a case study of a public hospital in South Africa, this paper charts the readiness of its management principles and activities to provide quality health care linked to population health and to contribute to the non-medical determinant of health. Using Taylor's principles of good governance, we conclude that there is a mixture of good and not so good governance activity. The paper concludes by examining the external constraints on the public hospital and by providing suggestions for future activities.
\end{abstract}

\section{Keywords}

Social Determinants of Health, Healthcare System, Public Hospitals, Governance and Governance Principles, South Africa 


\section{Introduction}

The purpose of this paper is to examine the significance of governance structures and processes in a public hospital in South Africa and its relationship to the actions necessary to further population health in the most unequal society in the world. Health care delivery, especially hospitals, has become the Cinderella determinant. This is the case in South Africa where significant inequities in population health exist. Despite social transfers, income inequality has hardly changed and remains high partly because the number of jobs created over the past 20 years barely kept pace with growth in the labour force [1]. Benatar notes that neo-liberal and globalizing trends have exacerbated the inequities of the apartheid era [2]. As Ataguba et al. note, in South Africa, poverty, inequality in socio-economic status and inequality in access to basic social services between population groups, provinces, and socio-economic groups are typical and extensive [3], remaining in place for over three decades [4]. In 2009, the World Health Organization (WHO) pointed to the importance of the environmental, psychosocial and structural determinants of health since taken up by many researchers in low and middle income countries. Ataguba et al. comment that "globally, it is recognized that health and health outcomes are not only affected by healthcare or access to health services. They result from multidimensional and complex factors linked to the social determinants of health, which include a range of social, political, economic, environmental and cultural factors, including human rights and gender equality" [5] [6]. In the 2003 version of the solid facts about the determinants of health, Wilkinson and Marmot set up this complexity but note that: "universal access to medical care is clearly one of the social determinants of health" [7]. Yet medical care is not one of their identified determinants. Documents of this access seem mainly discussed for disadvantaged populations [8]. Unmet medical need has been seen as a challenge among US African-American men [9]. Restricting access to care for refugees in Germany affected their abilities to benefit from care [10].

There can be no doubt about the unmet need and poor access to care among significant groups in the South African population, largely across racial, class and geographic lines with blacks, poor and rural citizens most likely to have poor health and poor access to health care [11]. So, access to and the distribution of medical services remains key. And this is particularly important for those who gain access to care through the public system, which is totally 84 percent of the population in South Africa [12]. In 2009, the South African Human Rights Commission reported that the public health care system was in a "lamentable state", exacerbated by the huge burden of HIV/AIDS, high income inequality and the gap between public and private health that affected affordability and quality of service [13]. This has become a reasonably well-researched issue, especially for district and clinic services but less so for hospitals despite their dominance of the health care budget. Not only is there interest in clinical competencies in hospitals and their involvement in non-medical determinants of health but also technical and managerial functionality. In the case of South Africa, expenditure on district hospitals alone has increased by $70 \%$ in real terms since 2005/06, accounting for 
about $37 \%$ of district health services in 2014/15 [14]. It is also reported that public sector hospitals consume about R70 billion of the health budget ${ }^{1}$, which stood at R36.46 billion for the 2015/2016 financial year and R33.95 billion for the 2014/2015 financial year [15].

Thus the interest in clinical competencies in hospitals and their involvement in non-medical determinants of health as well as the technical and managerial functionality [16] has been noted. Slipicevic and Masic note four managerial areas of significance, namely interpersonal, information management, analytic and action skills [17]. For South Africa, Pillay notes that public sector managers reported that they felt most competent in planning, self-management and leading and least competent in terms of legal/ethical competencies and their specific health care skills [18]. He concludes that "the fact that public sector managers have rated themselves as at least 'reasonably competent but not good' in all of the competencies suggests that they lack confidence in their ability either because they don't possess the requisite management skills or because they more generally lack self-belief [18]. Either way, this is a potential hindrance to the reconceptualization of the public sector into a more customer-oriented service and suggests that public sector managers need more training in management skills" [18]. Furthermore, Von Holdt showed that large sections of the South African state including public hospitals are institutionally ineffective and dysfunctional [19]. Thus public hospitals in South Africa are reportedly both dysfunctional and highly stressed institutions [20] [21]. Dysfunctional organizational structures within the hospitals undermine effective management [19]. Lack of management capacity can exacerbate management failures preventing the integrated management of operations, paralyzing initiative and preventing accountability, leading to a pervasive disempowerment of managers and an experience of managerial vacuum on the part of staff [21]. Schneider et al. noted that on-going and worsening staff shortages, particularly of skilled health workers have placed additional strain on the health system, especially the public hospitals [22]. "Demoralized and demotivated are common descriptors of health care providers and many are thus making use of opportunities to leave the public health system" [22]. This may generate a state of frustration and conflict within occupational categories, between occupational categories, within management, and between staff and management [21].

Managerial competence is vital for complex institutions like hospitals which have to deal not only with external actors (funders, competency auditors) but also with implementing-action skill-plans internally, given constraints of budget and resources [23]. The South African government has recognized the needs for reform and much attention has been paid to primary health care and regulatory compliance as seen through the program for National Health Insurance [24] and the National Development Plan [25]. But we argue thatthe efficient and effective governance of the public

${ }^{1}$ Press statement by the Minister of Health, Dr Aaron Motsoaledi on orientation program for newly appointed CEOs at the Birchwood Hotel, Johannesburg on February 4, 2013. Last accessed on November 16, 2015. http://www.gov.za/press-statement-minister-health-dr-aaron-motsoaledi-orientation-programme-newly-app ointed-ceos 
hospital sector is vital to improve patient and population health and enshrine their role in enhancing the determinants of health, medical and non-medical. The Health System Trust in 2012 noted that public hospitals performed poorly in positive and caring attitudes, and performed relatively well on waiting times and intermediately on patient safety, cleanliness and availability of medications [26]. Managers are often not allowed to manage. The Development Bank of Southern Africa (DBSA) in 2011 also reported that many of the traditional functional roles of CEOs are housed within the administrative chain above the CEO, including finance, Human Resources and strategic matters. In the strictest sense, the CEO's role is often reduced to managing the day to day running of a hospital [27]. Hospitals are a minor part of the NHI reforms with their being required to provide services based on their category of hospital. Others are linking to private providers in public-private partnerships to maintain benefit and lower cost [28]. Perhaps the most important development is the creation of the Academy for Leadership and Management in Health Care, established by the Health Minister, to overhaul dysfunctional and often inept leadership at public hospitals. In an op-ed, written after many CEO meetings across the country, Bateman noted that "the most valuable (and loudest) feedback from the national CEO group was that their success relies on having appropriately qualified, properly appointed managers below them, and the leadership and management chain above them being competent and functional" [29] [30]. Jacobs [Academy Chair] summarized: "They asked us to make sure that the nature and competencies of all managers in the system were aligned with their qualifications-and to look at the line going up to provincial and national levels-and also the teams within these institutions. Other critical issues they wanted addressed were on-the-job support and mentoring, peer networking and a clear determination of their own 'delegations' [job descriptions]" [30]. This provides a solid start for ensuring two of the core health competencies, leadership and corporate governance and operational management [31].

\section{Governance and Its Principles}

Hospitals are not only important institutions for medical care but their role in helping recognize the salience of the social determinants of health is increasingly noted. Thus the Canadian Institute of Health Information (CIHI) identifies the role of population characteristics, such as level of education, proportion of disadvantaged populations, in shaping the efficiency of hospital performance [32]. Hadad et al. identify the importance of the same issues in nine OECD countries [33]. The New York Health Foundation (NYHF) comments that hospital "involvement in programs impacting community non-medical health determinants is not widespread, owing to a perceived lack of incentives and resources for such programs. Nevertheless, some hospitals have developed programs addressing non-medical health determinants-such as access to healthy foods and parks, housing, and employment-by partnering with community organizations and local government. These programs require relatively little investment; they leverage the hospital's key role and relationships in the community to catalyze change [34]". 
Furthermore, in their action framework for the social determinants of health, WHO strongly advocates the need for new governance models. All sectors must be coordinated to ensure progress to better health and development [35]. Good governance for health is required for good governance in general because of health being a macroeconomic factor [36]. Hospital governance matters in this too, especially if they operate on principles of social responsibility such as abstention of harm to the environment, the protection of the interests of all the stakeholders enrolled in the delivery of health care and adequate corporate governance and corporate strategy [37]. Indeed some 40 years ago and in the context of NHI plans in the US, Hiatt noted the importance of social priorities for hospitals [38]. Yet policymakers are still grappling with the question of what constitutes good hospital governance, how to improve it, and how it contributes to better health systems [39]. In this study, hospital governance is defined as:

A set of processes and tools related to decision-making in steering the totality of institutional activity, influencing most major aspects of organizational behavior and recognizing the complex relationships between multiple stakeholders. Its scope ranges from normative values (equity, ethics) to access, quality, patient responsiveness, and patient safety dimensions. It also incorporates political, financial, managerial as well as daily operational issues [40].

This governance process is orchestrated by boards and executive managers constituting the axis of "hospital governance" [41] [42]. But Eeckloo and Abor et al. consider that hospital boards and managers are challenged by several major developments in health care and health care policy including the importance of considering the role of political and social actors in service delivery. In South Africa, as we have noted, public hospitals have undergone reforms since 2012 concerning leadership and management to ensure that the management of hospitals is underpinned by the principles of equity, efficiency, effectiveness, transparency and openness [43]. The role of these contexts has been noted in Central and Eastern Europe (CEE) and the Former Soviet Union where the combined influence of the external environment and organizational structure constitutes a significant determinant of hospital performance [44]. Moreover, both internal and external accountability factors including persistent ineffective accountability mechanisms have created an inconsistent incentive environment, where rewards and sanctions are not related to performance. Consequently, hospital management often lacks autonomy to make changes needed to improve productivity and efficiency [44]. In this paper we drill down to the internal governance picture to comment on the propensity of a hospital to be able to be accountable to stakeholders and address the non-medical determinants of health in partnership with others.

We use Taylor's nine principles of good governance [45], which he argued could be applied to health care management. Since his conceptualization, the principles have been applied and cited in fifty-nine other studies on governance in various fields. Seventeen of these specifically focused on health and healthcare with seven previous research focusing on hospital governance in New Zealand and the Czech Republic [41]; 
Ghana [46]; the Netherlands [47]; Portugal [48]; and Indonesia [49]. In South Africa, reference has been made to Taylor's principles in a study analyzing improved methods for funding public hospitals [50]. But this paper is the first to use them to investigate good governance and management implications in South Africa. Table 1 is a summary of the principles and implications.

Table 1. D. W. Taylor's Principles of good governance.

\begin{tabular}{ll}
\hline Principle & Application \\
\hline
\end{tabular}

1) Knowing what governance is.

2) Achievement of Strategic ends.

3) Board-CEO Relationship.

4) Unity of Direction.

5) Unity of command.

6) Unity of accountability and responsibility.

7) Ownership needs.

8) Self-improvement and quality management.

9) Understanding the cost of governance.
CEO is responsible to board for implementing its plans and strategic direction. Board is responsible for developing corporate policies and plans; monitoring and measuring organizational performance against those policies and plans; and acting as the voice of the ownership of the hospital. Board's governance responsibilities are to provide a linkage between the hospital and its moral ownership; monitor the performance of the CEO; and develop an explicit statement of values for the hospital.

To be effective by providing the right service, at the right place, at the right time and at an affordable cost.

Relationship is typified by a high level of mutual trust and confidence throughout the organization and particularly between the board of directors and CEO. Governance viewed as a solemn partnership between the board and CEO. Board members and the CEO are equals, colleagues. Organizations should be conceived of as a number of concentric circles with clients in the uttermost circle and the CEO in the inner circle.

The CEO and Board should function as a common body to pursue a common end. There should be only one board of governance, one $\mathrm{CEO}$, one strategic plan, mission or vision, at any one time.

Orders should be received from one superior only. Decision making authority should flow in a straight line from the top to the bottom of the organization.

Authority is derivative of responsibility. Every employee, including the CEO, must be held accountable for the exercise of authority in executing his/her responsibilities.

A hospital board's ultimate accountability is to the organization's ownership.

Continuous improvement should be part of an organizational philosophy and should permeate all aspects of hospital management and governance practice.

Understanding cost of governance is about board members personal opportunity costs, direct board meeting expenses, the costs of staff supporting board activities, the costs associated with errors made by the boards, and costs of ineffectively structured governance-management-organization relationships.

Source: [41] [45] [46]. 
According to the guidelines of the policy on public hospital management, hospital management uses an accountability framework that encompasses the interests of all stakeholders such as the community, the state, service providers, hospital boards and management in the public health care environment. Accountability is broadly defined in the policy to include community participation and involvement in the management of hospitals. What does the application of Taylor's principles show in a South African public hospital?

\section{Methodology}

\section{Design, Study Setting, Sampling and Data Collection}

Our study is based on a case study design aimed at providing in-depth understanding, through an exploratory qualitative inquiry on the governance system in place in a medium size district hospital in the North West province of South Africa. As Yin argued, case study methods are being rediscovered in health services research and have been applied to numerous studies of single facilities such as health centers, hospitals, and community mental health centers [51] (e.g., Bellin, Geiger, and Gibson, 1969; cited in Yin, 1999: p. 1210). This was, therefore, more appropriate as our objective was to investigate the governance structures and processes in detail. Also, as our aim was to explore and analyze the governance structures and processes so as to produce findings derived from real world settings [52], a qualitative case study approach was the most appropriate. We sought the "voices of participants" [53] in order to build a clear picture of the governance structures and processes. Qualitative research of this type is premised on the assumption that the interviewer will record testimonies which contain a mixture of verifiable fact and opinion which can only be understood through cross referencing of differing versions of the issues under discussion [54]. The versions of the executive management, middle management and operational management provide these differing accounts.

The study was conducted in only one district hospital in a sub-district. Its population consists of over 1.5 million people in half-million households. Mining, tourism, agriculture, enterprise development, manufacturing utilities, infrastructure and construction, and finance make up the main economic sectors [55]. According to the 2013/14 District Health Barometer (DHB), the majority of the population (68.3\%) is aged 15 to 64 years. The district has estimated medical scheme coverage ${ }^{2}$ of $13.1 \%$. The district itself is in the mid socio-economic quintile and as recorded in the District Health Information system (DHIS) Software, there are four district hospitals and one regional hospital [55].

Fifteen managers comprising executive management, middle and operational level managers were involved in the in-depth interviews. Participants were purposefully selected following a review of public hospitals organograms and later the specific organogram of hospital X. Participants included the CEO, the Clinical Manager, the deputy director, Corporate Services and the Deputy Director for Nursing Services making up

${ }^{2}$ Private health insurance protection. 
the Executive management. The middle level managers comprised the assistant director in charge of Finance and supply chain management, the acting human resources manager, the human resources development manager, assistant director, technical and support services, pharmacy manager, acting assistant director, quality assurance, who also doubles as senior administration officer, occupational health and safety, and the senior information services manager. At the operational level, participants included the manager responsible for the Outpatients Department (OPD), for theatre, for complaints and step-down ${ }^{3}$, and for the medical ward. The inclusion of the selected participants was based on their roles and responsibilities in the day to day management of the hospital. Nonetheless, while the views of service objects of hospitals-patients are important to a full understanding of good governance in hospitals concerning how the hospitals function; we took an internal view of good hospital governance in relation to the social determinants of health. Thus, patients' views were outside the scope of this study. This is, however, an important area for further investigation. Indeed, the reflections of patients could promote good governance ideals in all health care agencies and organizations, of which hospitals are part.

In terms of socio-demographic and clinical characteristics of the participants, the age range is between twenty and sixty years with majority being in the forty to fifty year age bracket. With regards to gender distribution across the three levels in the management of the hospital, female managers dominate. Out of the fifteen participants interviewed, ten were females and male males. Perhaps, the CEO argument that men are not good nurturers could explain this. Diverse fields of education were witnessed in the qualification of the managers. While educational qualifications range between Matric (Secondary Education) and MBA, fields of education vary. There's dominance of nursing qualifications among Operational and senior managers while public administration, financial management, B.Com in Administration and law characterize corporate management. The Senior and Operational managers' field of education, particularly, of the nursing profession is in line with the Policy on the Management of Public Hospitals, which requires CEOs, for instance, and other managers to have a health background.

All the interviews took place at secured locations in the work places or offices of the participants, mostly during working hours. Questions were specifically adapted for each category of managers and aimed to discover their roles and responsibilities in the management of the hospital. Questions also centered on the governance system and processes in the hospital; the skills and competencies required to functioning effectively within the governance framework; and the challenges encountered in the management of the hospital. Other areas that interview questions covered were major governance issues they have had to deal with over the years; the management culture and practices and whether these are changing over the years; board and management meetings and frequency and what can be done to improve the governance of the hospital. In order to avoid the potentials of participants leaning towards possible questions of health care in 
view of their clinical or health background, we adopted the "grand-tour" approach where respondents were steered toward a small number of key interview destination issues but also encouraged to talk in terms that came naturally to them [56]. This ensured interview subjects stayed within the scope of the study objectives.

Each interview lasted between 30 - 60 minutes with the exception of four that went beyond an hour. Originally, the intention was to include the board chair and other board members in the interviews as the board is an important element of Taylor's framework, which has been adopted as a guide and in the overall governance structure of the hospital. However, at the time of the study, it was reported that the hospital had no duly constituted and functioning board as it had been dissolved the previous year due to political reasons. We attempted to contact the past Board chair who refused to be interviewed. This is a limitation that we duly acknowledged in this study. We also acknowledged the fact that the study was conducted in one medium-size district public hospital and hence findings cannot be generalized about all similar size public hospitals in South Africa due to different local contextual factors. The first author conducted all the interviews in English in March 2015.

After the interviews were transcribed, a coding scheme was developed using NVivo 10 software, which involved placing extracts from the data in a thematic grouping procedure. Themes, derived from recurring interview content, included the governance structure as it exists in the hospital, roles and responsibilities of the different categories of managers, policies, rules and regulations by which units and departments are managed. The themes are presented and analyzed in line with Taylor's framework.

The study received ethics approval from the University of the Witwatersrand Research Ethics (Medical) Committee and from the North West Department of Health. Respondents were provided with information sheet about the study.

\section{Results}

\subsection{Mission and Vision Statements, Values and Goals}

Hospital X has clear vision and mission statements, and core values are displayed on notice boards of the hospital. The vision of the hospital is to "collaborate with communities and all stakeholders in Local Municipality for better health for all". Its mission is to be in "partnership with its catchment communities to render a quality, comprehensive and integrated Primary Health Care (PHC) services within the limitations of the law, culture of the clients and within available resources". Its mission statement thus highlights community participation and indirectly the non-medical determinants of health. The core values of the hospital were referred to as PRIDE: professionalism/ privacy, Respect, Integrity, Diversity/Dependability and Empathy. Although the hospital had no functioning board at the time of the study, it was revealed that in terms of membership, the board consists of eighteen members, of whom three are hospital staff with no voting rights, effectively leaving the board with fifteen decision-making members. Representation on the board is according to various interests of the area including the local municipality, youth, the disabled, the district council and a representative of 
sub-district health council. If the Board does not exist, how were the CEO and executive management appointed? The CEO was appointed by the Deputy Director- General for Health in the province without reference to local stakeholders. Usually the political Member of Executive Council (MEC) and the Head of Department (HOD) of the individual province appoint the CEO. Thus the Hospital X appointment contravened both Taylor's principles and the present practice in South Africa.

Evidence from the interviews suggests that the hospital board was dissolved because of issues of "knowing what governance is".

Then another governance issue was the relationship between the Board and the CEO. The Board said: "we fired the CEO" and I was like what? They said " and you must look at us... we will make sure we mobilize the community". Then I got to know that the Board had cancelled interviews on recruitment to fill posts in the hospital if they were not invited to sit in on such interviews (CEO).

Board members tend to forget the reason why they have been appointed. They actually bring politics, because most of them are politicians... bring politics into the Institution, not focusing on health care, and the reason why they have been appointed (Finance and Supply Chain Manager).

We had some shortcomings before, more especially, in terms of governance. The hospital board was really holding the institution to ransom. How do you put in a board member into the shortlisting of candidates for the hospital? For instance, even tuck shop for the hospital, they want to get favors... they interfere too much in the administration (management). They even organized some of the marches to come and march against the hospital management (Corporate services manager).

Thus the board seemed to fail to perform its non-delegatable responsibility of providing a linkage between the hospital and its moral owners (community). It became a local political agency for self-interest by interfering in the work of management and the production of good governance. Thus as noted by Lee et al., the board failed to identify the hospital's values, formulate policies, and shape strategic choices made by executives [57].

However, executive, middle and operational management appear to understand "what governance is". The CEO defines her role and responsibilities thus:

I $m$ a strategic manager who has to make sure that the hospital uses its resources effectively, it's able to have goals and objectives that are in line with national and the province and in so doing make sure that we are able to have the outcomes that have been agreed upon by the Minister and the President in Parliament (CEO).

Internal relations are vital for good governance. The CEO sees one role as dealing with the problems created by other managers below her.

Im a cleaner. People make a mess, I clean up. The MEC would go and talk to the community and promise them things. Then he would obviously make overpromises and you have to clean up. The doctors will mess up, they will cut this leg 
instead of that leg, and then you clean up (CEO).

For the clinical manager,

My job, broadly, can be seen as being two-fold. I'm involved in fashioning a strategic pathway of the hospital and the District, as a whole. On the other hand, I have to see to patient's issues, within the hospital, on a day-to-day basis (Clinical manager).

Management involves this linkage to the district with its community perspective. Other middle level and operational managers explained their roles and responsibilities in the governance framework of the hospital.

I do all the data management in the hospital. We have got policies that we have to work accordingly, so all the database gets captured at clinic ward levels, programme levels. All that data get on a paper based format sent to us on a monthly basis (Senior Information Officer).

I supervise nurses. I ensure that all the nurses do their duties. I delegate them. I make off-duties for them. I teach them conditions, see to it that they report to duty on time. That is to see that they conduct all their duties as supposed to (Operational Manager, Medical Ward).

\subsection{Resources and Achievement of Strategic Ends}

Nearly all respondents at all levels of management complained of budgetary constraints as a militating factor against achieving the core mandate of the hospital:

We also have budgetary constraints. We rely on how much of a cake did health get given in Parliament and provincially and to the institution (CEO).

Budget is a huge problem. Why I said budget is a huge problem is that, for instance, the maintenance budget is centralized, it is at a district office... (Assistant Director, Technical and Support Services).

A major consequence of these budgetary constraints is shortage of staff, especially, clinical staff leading to increasing workload, stressed staff, long waiting times for patients. This has also resulted in using less qualified personnel in functional areas, resulting in task-shifting [58], which is common in South Africa, but may not provide effective care. It also means that many managers are not trained as such and are at a disadvantage of providing principled governance.

\subsection{Lack of Leadership Team at Hospital X}

In hospital X there is little evidence of a leadership team involving the board and CEO. As indicated earlier, the board claimed to have fired the CEO and mobilized the community against hospital management. It also cancelled interviews to recruit staff to fill vacancies if they (the Board) were not invited to be part of the interview panel. This view was corroborated by other members of the executive management: 
The hospital board was really holding the institution to ransom. The way they were operating the first time I came here, ... we were doing shortlisting and according to them they are part of the shortlisting and of the interview. You find that the person coming cannot even write his name as a hospital board member or the knowledge is just not there (Deputy Director, Corporate Services).

The board sought to interfere in many aspects of management including procurement. The interviewee lamented: "just tuck shop for the hospital they interfere, they want to get favors". The interviewee concluded strongly that "there was no good relationship with the community and the hospital because of the hospital board". This situation undermined mutual trust and confidence within the hospital. In effect, there was no unity of direction between the board and the CEO/management. The board was not functioning to ensure good, respectful hospital governance as the question remains as to how the board could fire the $\mathrm{CEO}$ as its role does not include this appointment. Furthermore, the board also affected the external relations of the hospital, especially, in that the board did not enhance the organization's reputation, establish external contacts and advice and counsel the CEO to deal with population health needs.

\subsection{Common and Direct Reporting Lines}

Participants explained that there are direct reporting lines in the governance structure, reflecting Taylor's principle of unity of command.

There are direct reporting lines, you know, from the National Department of Health, down to the Provincial offices, down to the District. At the District level we have our Directors there, our Chief Directors, who liaise directly with our Chief Executive Officers and then when you look at that, then you will come into the organogram of the institution itself. I report directly to the Chief Executive Officer of the hospital (Clinical Manager).

There was clear indication of this kind of unity of command in the hospital itself. While this principle requires the CEO to directly report to the board, there is evidence that sometimes CEOs deal directly with the MEC for health at the provincial level.

"The MEC said to me, no I know about your Board, we are disbanding it. He asked do you have a problem and I said no, take it out. They took out the Board' (CEO).

Unity of command in the hospital is seen in operational units which lead to the effective provision of services. Nurses report directly to their operational managers in the various units, who in turn report to the deputy director of nursing services, clinicians report to the clinical manager, while administrative staff report to their middle level managers who then report to the deputy director for corporate services. There are also instances where middle level managers report directly to the CEO instead of their immediate superiors.

As $I$ am acting quality assurance $P \mathrm{~m}$ reporting to the CEO. But when $I m$ doing my Senior Admin job, $1 \mathrm{~m}$ reporting to Quality Assurance (Quality Assurance and 
Occupational Health and Safety).

\subsection{Accountability and Responsibility}

Accountability and responsibility are key in the governance structures of the hospital. All participants made reference to the performance management system in place and employees' responsibility and accountability and supervisors' responsibility for ensuring these are achieved:

We call it public service performance management. The managers sit down with those under them to agree on the Key Performance Areas (KPAs). They will then have a performance contract for the year (CEO).

Like I mentioned, the Public Management Development System (PMDS); which is a performance management tool that we use a lot in the public sector and it applies to all the employees. The PMDS is a well-structured tool and what it does is for employees to periodically go through a kind of a formal assessment process. Are you really delivering the goods and so on?" These are key performance areas with key performance indicators (Clinical Manager).

From the perspectives of executive management, the performance management system ensures both superiors and subordinates have unity of responsibility and accountability; as it involves monitoring responsibilities of employees. These views were corroborated by both middle and operational level managers.

We've got what is called a performance management development program, where on quarterly basis there is a review of your performance between you and your supervisor... what is expected from you as an individual (Acting Assistant Director, Quality Assurance and Occupational Health and Safety).

References were made to the fact that approval of appointments and budget is carried at the provincial level, limiting the ability of managers to staff the institution. Politically, therefore, decision space and authority for CEOs is restricted due to hierarchical control and centralization at the provincial level. The role of the external partner, the province, in determining budget level and remit must be underscored. Another important aspect of accountability concerns patients and their communities. It was revealed in hospital $\mathrm{X}$ that managing the expectations of clients has been difficult.

Our ability to service the clients, and then we also have problems of attitude, managing the expectation of our clients. It's a hospital and people out there actually come in with different expectations of what they feel the institution should be able to do for them. Then often you find out that those expectations are not well aligned with what we can really deliver as a hospital (Clinical Manager).

Thus, delivering the best services possible with available resources and at the same time being accountable to the province, national office of health standards compliance and the community provides the context for the hospital being answerable to all these stakeholders. Hospital X may not be at the best starting point to responding to popula- 
tion health needs:

When you analyze it further you would then see that on average, most of the departments are functioning at 50\%. It s just unfortunate that OT is at $0 \%$; and it is

OT, speech and physio that are dragging the percentage because if you would take those out, you would see that possibly the percentage would improve (CEO).

The community is not always onside and the CEO noted that: "some bad episodes and the community's perception about the hospital based on hearsay have really led to loss of trust in the hospital as an organization"; often times with community members sometimes "throwing stones at us". This in turn, has affected the ability of the hospital to be accountable to the community. This, notwithstanding, within the management of the hospital, unity of accountability and responsibility apparently permeates the managerial structure as seen in the performance management system.

\subsection{Continuous Self-Improvement}

This principle permeates the hospital management as interviewees reported various training programs both at the hospital level and outside the hospital:

We have in-service training. We also have trainings that are organized by NGO's on behalf of National Department of Health and I think it is not the lack that we are having a problem with (CEO).

We do an induction with them. The hospital does an official one, so that they know how the hospital functions, the protocols, procedures, leaves, and that sort of thing, and then I always have a pharmacy induction also (Pharmacy manager).

Besides, self-improvement is continuous to update staff on current hospital management and practices:

We have continuous training on or about supervision and then even in-service trainings, on procedures that are done here, just to remind us (Operations Manager, Theatre).

However, continuous self-improvement program is lop-sided and discriminatory in favor of clinical and allied health professionals.

To tell you the truth, the plumber resigned now and one of his reasons was he wanted to go study further on and he knows we will not be able to send him. So, training is a huge problem (AD, Technical and support Services).

This was confirmed by the Human Resources Development manager, who is in charge of training and development in the hospital: "there's a perception that we concentrate on particular field, we take in nurses to study at college". It is, therefore, frustrating to the administrative staff leading to resignations or moving to the private sector, where opportunities for further self-development are available. This confirms earlier studies that a state of frustration and conflict can be generated within occupational categories, between occupational categories, within management, and between staff and 
management [58]. Management training opportunities are therefore sparse, meaning that the same applies to learning about good governance. This affects the ability of the hospital to function effectively as a unit. Again, it also came across that self-improvement of administrative staff comes in areas that are not, particularly, relevant to their work functions:

When it comes to do a code of conduct training, they go for that, but the relevant training for them, for example, let's say I want to send an electrician for air con training that is relevant to the work, it is not happening, because of the problems of budget (AD, Technical and Support Services).

\section{Conclusions and Implications}

In this study, we examined the governance structures and processes in a South African public hospital in relation to the role of hospitals and hospital governance in contributing to enhancing the social determinants of health. Good governance is vital not only for service delivery but also for community needs assessments and interventions. The hospital provides the centre-along with the clinic-where these activities do and can take place. Hospitals are major investments and must conform to the new policy environments being created nationally and internationally. We used Taylor's nine principles of good governance, many of which were found, including knowing what governance is, understanding the cost of governance, self-improvement, unity of responsibilitylaccountability, and unity of command. However, the principles of board-CEO/ management relationships, unity of direction, and achievement of strategic ends appear problematic. This is consistent with earlier studies on hospital governance in New Zealand and Czech Republic [41] and Ghana [46], but accountable strategies and plans as well as community involvement are vital for new governance models.

What are the implications of this case study? The role of politics is crucial in constituting and truncating the life of the board. Politics, an unshakeable facet of all life in South Africa, must be channeled to ensure hospital management has freedom to execute its policies and plans as WHO and national policies point to health care integration and stakeholder participation. We assert that the role of the board must also be made more functional than normative as is the current case in South Africa.

Other external accountabilities must be recognized. Province is influential. It develops corporate policies and plans. It provides the budget. The national department of health provides operational guidelines. Yet most of them appear as impositions on hospitals bringing into question the extent to which the various stakeholders know what governance is and their role in attaining it. There is an argument for a greater partnership between province and its institutions to ensure clarity on the local impacts of policy decisions.

There are other implications: good hospital structures and processes can shape leadership practices and the achievement of hospitals' strategic ends. This observation is consistent with Jakab et al. conclusion that well designed hospital organizational structures and performance are interlinked [44]. However, in a study of the degree of hos- 
pital governance orientation towards quality and performance, Botje et al. establish that while hospital governance is important, it does not occur in a vacuum [47]. All hospitals are part of a wider health care system and of state social protection more generally. If hospital $\mathrm{X}$ is an indication, hospitals are moving toward good governance internally with attention paid to leadership and performance appraisal but much needs to be done for it to contribute to the non-medical determinants of health and development more generally.

\section{Acknowledgements}

We acknowledge the funding received from the NRF/SARChI to conduct this study and we are also grateful to all the hospital staff who participated in the in-depth interviews. The views expressed in this paper do not necessarily reflect those of the funder.

\section{Conflict of Interest}

We declare that we have no conflict of interest.

\section{References}

[1] Keeton, G. (2014) Inequality in South Africa. Helen Suzman Foundation, 1, 26-31.

[2] Benatar, S. (2013) The Challenges of Health Disparities in South Africa. SAMJ: South African Medical Journal, 103, 154-155. http://dx.doi.org/10.7196/SAMJ.6622

[3] Ataguba, J.E., Akazili, J. and McIntyre, D. (2011) Socioeconomic-Related Health Inequality in South Africa: Evidence from General Household Surveys. International Journal for Equity in Health, 10, 48. http://dx.doi.org/10.1186/1475-9276-10-48

[4] Møller, V. (2013) South African Quality of Life Trends over Three Decades, 1980-2010. Social Indicators Research, 113, 915-940. http://dx.doi.org/10.1007/s11205-012-0120-y

[5] Ataguba, J.E.-O., Day, C. and McIntyre, D. (2015) Explaining the Role of the Social Determinants of Health on Health Inequality in South Africa. Global Health Action, 8, Article ID: 28865. http://dx.doi.org/10.3402/gha.v8.28865

[6] Halfon, N., Larson, K. and Russ, S. (2010) Why Social Determinants? Healthcare Quarterly, 14,8 .

[7] Wilkinson, R.G. and Marmot, M.G. (2003) Social Determinants of Health: The Solid Facts: World Health Organization.

[8] NCCAH (2011) Access to Health Services as a Social Determinant of First Nations, INUIT and MÉTIS Health.

[9] Tucker-Seeley, R.D., Mitchell, J.A., Shires, D. and Modlin Jr., C.S. (2015) Financial Hardship, Unmet Medical Need, and Health Self-Efficacy among African American Men. Health Education \& Behavior, 42, 285. http://dx.doi.org/10.1177/1090198114557125

[10] Bozorgmehr, K. and Razum, O. (2015) Effect of Restricting Access to Health Care on Health Expenditures among Asylum-Seekers and Refugees: A Quasi-Experimental Study in Germany, 1994-2013. PLoS One, 10, e0131483.

http://dx.doi.org/10.1371/journal.pone.0131483

[11] Coovadia, H., Jewkes, R., Barron, P., Sanders, D. and McIntyre, D. (2009) The Health and Health System of South Africa: Historical Roots of Current Public Health Challenges. The Lancet, 374, 817-834. http://dx.doi.org/10.1016/S0140-6736(09)60951-X 
[12] South Africa (2012) Health Care in South Africa.

http://www.southafrica.info/about/health/health.htm\#.V645mv5o3IV

[13] SAHRC (2009) Public Inquiry: Access to Health Care Services. A Report and Recommendations Based on the Submissions and Proceedings of Public Hearings Conducted at the National Office of the South African Human Rights Commission, Parktown, Johannesburg from 30 May to 1 June 2007.

[14] Day, C. and Gray, A. (2015) Health and Related Indicators. South African Health Review, $15,198-332$.

[15] Republic of Africa (2015) Minister Aaron Motsoaledi: Health Dept Budget Vote 2015/16. http://www.gov.za/speeches/minister-aaron-motsoaledi-health-dept-budget-vote-201516-5may-2015-0000

[16] Greiner, A.C. and Knebel, E. (2003) Health Professions Education: A Bridge to Quality. National Academies Press, Washington DC.

[17] Slipicevic, O. and Masic, I. (2012) Management Knowledge and Skills Required in the Health Care System of the Federation Bosnia and Herzegovina. Materia Socio Medica, 24, 106-111. http://dx.doi.org/10.5455/msm.2012.24.106-111

[18] Pillay, R. (2008) Managerial Competetncies of Hospital Managers in South Africa: A Survey of Managers in the Public and Private Sectors. Human Resources for Health, 6, 4. http://dx.doi.org/10.1186/1478-4491-6-4

[19] Von Holdt, K. (2010) Nationalism, Bureaucracy and the Developmental State: The South African Case. South African Review of Sociology, 41, 4-27. http://dx.doi.org/10.1080/21528581003676010

[20] Von Holdt, K. and Maserumule, B. (2005) After Apartheid: Decay or Reconstruction? Transition in a Public Hospital. In: Webster, E. and Von Holdt, K., Eds., Beyond the Apartheid Workplace: Studies in Transition, University of KwaZulu-Natal Press, Scottsville.

[21] Von Holdt, K. and Murphy, M. (2007) Public Hospitals in South Africa: Stressed Institutions, Disempowered Management. In: Buhlungu, S., Daniel, J., Southall, R. and Lutchman, J., Eds., State of the Nation: South Africa 2007, HSRC Press, Cape Town, 312-341.

[22] Schneider, H., Barren, P. and Fonn, S. (2007) The Promise and the Practice of Transformation in South Africa's Health System. In: Buhlungu, S., Daniel, J., Southall, R. and Lutchman, J., Eds., State of the Nation: South Africa 2007, HSRC Press, Cape Town, 289.

[23] Burnett, S., Mendel, P., Nunes, F., Wiig, S., van den Bovenkamp, H., Karltun, A., et al. (2016) Using Institutional Theory to Analyse Hospital Responses to External Demands for Finance and Quality in Five European Countries. Journal of Health Services Research \& Policy, 21, 109-117. http://dx.doi.org/10.1177/1355819615622655

[24] DoH (2015) National Health Insurance for South Africa: Towards Universal Health Coverage. Department of Health, Pretoria.

[25] NPC (2012) National Development Plan 2030: Our Future-Make It Work.

[26] Visser, R., Bhana, R. and Monticelli, F. (2012) The National Health Care Facilities Baseline Audit National Summary Report. HST, Durban.

[27] E-Health News (2011) DBSA Report on Hospital CEOs.

[28] OBG (2016) Reforms and a New Strategy Aim to Improve South Africa's Health Sector. Oxford Business Group, Oxford. http://www.oxfordbusinessgroup.com/overview/what-doctor-ordered-recent-improvement s-and-new-strategy-provide-strong-foundation-future-growth

[29] Bateman, C. (2013) Hope at Last for Crisis-Ridden Gauteng Academic Hospitals? South 
African Medical Journal, 103, 705-706. http://dx.doi.org/10.7196/SAMJ.7469

[30] Bateman, C. (2013) Health Leadership Training Academy Tackles Worst First. South African Medical Journal, 103, 707-708. http://dx.doi.org/10.7196/SAMJ.7480

[31] Padarath, A. and English, R. (2011) South African Health Review 2011. Health Systems Trust, Durban.

[32] CIHI (2014) Measuring the Level and Determinants of Health System Efficiency in Canada.

[33] Hadad, S., Hadad, Y. and Simon-Tuval, T. (2013) Determinants of Healthcare System's Efficiency in OECD Countries. The European Journal of Health Economics, 14, 253-265. http://dx.doi.org/10.1007/s10198-011-0366-3

[34] NysHealth (2016) The Role of Hospitals in Improving Non-Medical Determinants of Community Population Health.

[35] WHO (2016) Social Determinants of Health. WHO. http://www.who.int/social_determinants/en/

[36] Kickbusch, I. and Gleicher, D. (2012) Governance for Health in the 21st Century. World Health Organization, Geneva.

[37] Brandao, C., Rego, G., Duarte, I. and Nunes, R. (2013) Social Responsibility: A New Paradigm of Hospital Governance? Health Care Analysis, 21, 390-402. http://dx.doi.org/10.1007/s10728-012-0206-3

[38] Hiatt, H.H. (1975) Protecting the Medical Commons: Who Is Responsible? New England Journal of Medicine, 293, 235-241. http://dx.doi.org/10.1056/NEJM197507312930506

[39] Brinkerhoff, D.W. and Bossert, T.J. (2014) Health Governance: Principal-Agent Linkages and Health System Strengthening. Health Policy and Planning, 29, 685-693. http://dx.doi.org/10.1093/heapol/czs132

[40] Durán, A., Saltman, R.B. and Dubois, H.F. (2011) A Framework for Assessing Hospital Governance. In: Governing Public Hospitals, WHO, Copenhagen, 35-53.

[41] Ditzel, E., Štrach, P. and Pirozek, P. (2006) An Inquiry into Good Hospital Governance: A New Zealand-Czech Comparison. Health Research Policy and Systems, 4, 2. http://dx.doi.org/10.1186/1478-4505-4-2

[42] Eeckloo, K., Van Herck, G., Van Hulle, C. and Vleugels, A. (2004) From Corporate Governance to Hospital Governance. Authority, Transparency and Accountability of Belgian Non-Profit Hospitals' Board and Management. Health Policy, 68, 1-15. http://dx.doi.org/10.1016/j.healthpol.2003.07.009

[43] NDoH (2012) National Health Act, 2003: Policy on the Management of Hospitals. Government Gazette, Department of Health, Pretoria.

[44] Jakab, M., Preker, A.S. and Harding, A. (2003) The Missing Link? Hospital Reform in Transition Economies. In: Harding, A.L. and Preker, A.S., Eds., Innovations in Health Service Delivery. The Corporatization of Public Hospitals, Health, Nutrition, and Population, World Bank, Washington DC, 207-238.

[45] Taylor, W.D. (2000) Facts, Myths and Monsters: Understanding the Principles of Good Governance. International Journal of Public Sector Management, 13, 108-124. http://dx.doi.org/10.1108/09513550010338755

[46] Aseweh Abor, P., Abekah-Nkrumah, G. and Abor, J. (2008) An Examination of Hospital Governance in Ghana. Leadership in Health Services, 21, 47-60. http://dx.doi.org/10.1108/17511870810845905

[47] Botje, D., Klazinga, N.S. and Wagner, C. (2013) To What Degree Is the Governance of Dutch Hospitals Orientated towards Quality in Care? Does This Really Affect Performance? 
Health Policy, 113, 134-141. http://dx.doi.org/10.1016/j.healthpol.2013.07.015

[48] Alves Ad, S.D. (2011) Responsabilidade e governação na moderna gestão hospitalar.

[49] Indahwaty, A. and Sudirman, I. (2014) A Conceptual Model of Indonesia Hospital Accountability in Hospital Reformation Era.

[50] Ensor, T., Kruger, J. and Lievens, T. (2009) Improved Methods for Funding Public Hospitals in South Africa.

[51] Yin, R.K. (1999) Enhancing the Quality of Case Studies in Health Services Research. Health Services Research, 34, 1209-1224.

[52] Patton, M.Q. (1990) Qualitative Evaluation and Research Methods. Sage Publications Inc., Thousand Oaks.

[53] Creswell, J.W. (2007) Qualitative Enquiry and Research Design: Choosing among Five Approaches. Sage Publications Inc., Thousand Oaks.

[54] Undheim, T.A. (2003) Getting Connected: How Sociologists Can Access the High Tech Elite. The Qualitative Report, 8, 104-128.

[55] Massyn, N., Day, C., Peer, N., Padarath, A., Barron, P. and English, R. (2014) The District Health Barometer: Year 2013/14. Health Systems Trust, Durban.

[56] McCracken, G. (1988) The Long Interview. Vol. 13, Sage Publications Inc., Thousand Oaks. http://dx.doi.org/10.4135/9781412986229

[57] Lee, S.Y.D., Alexander, J.A., Wang, V., Margolin, F.S. and Combes, J.R. (2008) An Empirical Taxonomy of Hospital Governing Board Roles. Health Services Research, 43, 1223-1243. http://dx.doi.org/10.1111/j.1475-6773.2008.00835.x

[58] Von Holdt, K. and Murphy, M. (2007) Public Hospitals in South Africa: Stressed Institutions, Disempowered Management. In: Buhlungu, S., Daniel, J., Southall, R. and Lutchman, J., Eds., State of the Nation: South Africa 2007, HSRC Press, Cape Town, 312-341.

\section{Submit or recommend next manuscript to SCIRP and we will provide best service for you:}

Accepting pre-submission inquiries through Email, Facebook, LinkedIn, Twitter, etc.

A wide selection of journals (inclusive of 9 subjects, more than 200 journals)

Providing 24-hour high-quality service

User-friendly online submission system

Fair and swift peer-review system

Efficient typesetting and proofreading procedure

Display of the result of downloads and visits, as well as the number of cited articles

Maximum dissemination of your research work

Submit your manuscript at: http://papersubmission.scirp.org/

Or contact health@scirp.org 